\title{
Effect of Corporate Governance Board Characteristics on Performance of Microfinance Banks in Nigeria.
}

\author{
Ikechukwu Ehugbo
}

To Link this Article: http://dx.doi.org/10.6007/IJARAFMS/v11-i2/8953

DOI:10.6007/IJARAFMS /v11-i2/8953

Received: 03 April 2021, Revised: 30 April 2021, Accepted: 10 May 2021

Published Online: 25 May 2021

In-Text Citation: (Ehugbo, 2021)

To Cite this Article: Ehugbo, I. (2021). Effect of Corporate Governance Board Characteristics on Performance of Microfinance Banks in Nigeria. International Journal of Academic Research in Accounting Finance and Management Sciences, 11(2), 27-46.

\section{Copyright: @ 2021 The Author(s)}

Published by Human Resource Management Academic Research Society (www.hrmars.com)

This article is published under the Creative Commons Attribution (CC BY 4.0) license. Anyone may reproduce, distribute, translate and create derivative works of this article (for both commercial and non-commercial purposes), subject to full attribution to the original publication and authors. The full terms of this license may be seen at: http://creativecommons.org/licences/by/4.0/legalcode

\section{Vol. 11, No. 2, 2021, Pg. 27 - 46}




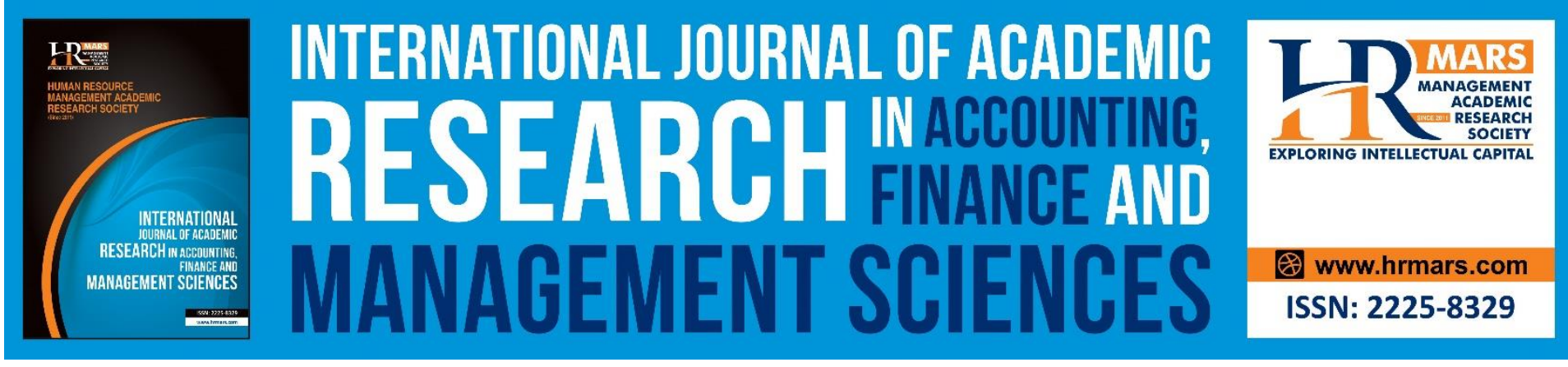

\title{
Effect of Corporate Governance Board Characteristics on Performance of Microfinance Banks in Nigeria.
}

\author{
Ikechukwu Ehugbo \\ Department of Business Administration and Management, School of Business and Financial \\ Studies, Cross River Institute of Technology and Management, Ugep, Nigeria. \\ Email: ikechukwuehugbo83@gmail.com
}

\begin{abstract}
This paper investigates the effect of corporate board characteristics on performance of microfinance banks in Nigeria. The study rationale is to ascertain how management of microfinance banks in Nigeria can enhance their performance through effective and efficient use of board of directors. Specifically, the study assesses the effect of board independence and board gender diversity on returns on assets and liquidity. longitudinal research design was used. The technique of sampling employed is simple random technique and Taro Yamane's formula used to determine the sample size at 284. Secondary data gotten from examined financial position of the chosen licensed microfinance banks in Nigeria between the five years period of 2015 and 2019. Pilot study was employed to test the reliability of the instrument. The result from the tested hypotheses reveals a substantial and positive correlation among board independence and return on assets of microfinance banks. The gender diversity has significant and negative influence on profit on assets of microfinance banks. Furthermore, the result on liquidity reveals a positive and significant relationship amidst board independence, gender diversity and liquidity of microfinance banks. However, it is observed from the study that women representation on boards of microfinance banks is still very low.
\end{abstract}

Keyword: Corporate Governance, Board Gender Diversity, Board Independence, Banks Performance, Liquidity

\section{Introduction}

The trend of globalization has heightened the choice and interest of investors towards evaluation of the strength of a firm before investing their wealth in order to ensure that their investments are secured and long-term financial stability of the firm is assured. Globalization has encouraged business exercises and prevalent execution has decreased the obstructions that exist in corporate exchange and financial venture, as it were that businesses have now a more noteworthy chance to develop. Therefore, firm accomplishment is the essential ingredient to entice investors. These brings to the forefront, the significance of governance business, which relates to both secluded and public establishments within a nation state. The 
MANAGEMENT SCIENCES

Vol. 11, No. 2, 2021, E-ISSN: 2225-8329 @ 2021 HRMARS

terminology corporate administration appeared into prominent used during the 1980's to obviously portray the overall standards by which tasks of business and executives of organization were coordinated and supervise (Dar et al., 2011). Corporate governance by way of definition is a mechanism and a systematic process to which organizational activities are conducted. Corporate governance acts a solution in offering planned route in establishing plainness and confidence among the shareholders and other investors.

Several incidents are accountable for the sharp notice in the issues of corporate administration and have given prominence and impetus to the concept of corporate governance in advanced and emerging nations. The incidence of Enron an energy company and Arthur Andersen an audit giant based in Houston, taxes which shock the whole world considering the level of their illegal and unethical operation has drawn attention to the business world near the necessity of corporate governance machinery. Rules of commercial supremacy was initially launched thru the Organization for Economic Cooperation and Developments (OECD) in 1999. Afterward, these instructions caught the consideration of immense partners like policies makers, investors and organizations. These codes or standards gives basic benchmarks of corporate administration and great practices that are material in dissimilar corporate arrangements (Akbar, 2014). Furthermore, this code serves as a guideline in operations of many organizations around the world. In Nigeria, the issues corporate governance practices have been given uppermost attention by all the segments of the country. For instance, the SEC (2003) formulate the Atedo Peterside Committee on corporate governance to investigate and proffer solution to corporate governance challenges in Nigeria public enterprises. These is in acknowledgement of the serious role of corporate governance in the achievement or disappointment of every enterprise (Ogbechie, 2006).

Great corporate practices encourage firms to enhance corporate routine and pull in financiers while empowering them to accomplish their corporate goals, met legal specifications, shield investors rights and exhibit to a wider public how their business is been directed. These training has turned out to be basic overall endeavors to balance out and fortify worldwide capital markets and secure financial specialists. Respectable businesses add to financial advancement by improving the performance of institutions and expanding their entrance to outside cash (Dar et al., 2011). Good corporate governance is aimed at maximizing shareholders wealth and placing the organization in a competitive position. Corporate governance on the other hand is concerned with maintaining a stability among fiscal and societal goals, and amidst personal and shared aims, whereas promoting efficient employment of resources plus greater levels of transparency (Vishwakarma, 2015).

The microfinance scheme was primarily introduced by CBN in response to the inability of the official monetary structure to aid the necessity of small salary households' population and micro venture. Over the years, government has introduced a set of sequences and documents endeavor to address the issues of lack of capital, eradication of poverty and unemployment among economic active population of the nation. However, handful of this program seize to attain the goals for which they were created and therefore, were abandoned (Acha, 2012). "The Central Bank of Nigeria, in consultation with other relevant agencies, included the microfinance policy as one of its initiatives that started in 2004, the policy was designed to boost capacity of micro, small and medium enterprises towards economic growth and development through financial intermediation (Nwaogazi, 2010), in spite of the well spelt out policy and objectives of microfinance banks, most of the institutions are threatened by sustainability and continuity in service delivery due to lack of competent board, considering the crucial role played by microfinance banks in the economic growth, the consequences of 
MANAGEMENT SCIENCES

Vol. 11, No. 2, 2021, E-ISSN: 2225-8329 @ 2021 HRMARS

weaknesses in its corporate governance operations will adversely affect the purpose for its establishment, and this factors therefore, informs the need to investigate the corporate governance systems of microfinance banks in Nigeria, in order to ascertain the extent to which they are managed and how it affect their performance in achieving their corporate objectives" ( $p ; 3)$.

\section{Statement of the Problem}

Microfinance Industries have significantly changed its shape and operations in the last few decades, owed to numerous motives in which corporate governance is also one of them, which acts as a pivot part to augment the performance of Micro-finance banks. An active management of this banks is needed due to its composite business as it offers saving, credit, loan and other monetary services mainly for the small income breadwinners in the community in order to aid them elevate their revenue levels and enhance their standard of living which will contribute to the socioeconomic growth of the nation. In spite of the crucial role of microfinance banks in Nigeria, in the economic development of the country; most of the institutions are threatened by issues such as poor representation of women on the board, lopsidedness in the appointment of directors, lack of competent board, inadequate number of directors and lack of proper financial auditing. More so, majority of microfinance banks in Nigeria have a twofold task, of low-income client in order to expand their prosperity, and a profit-making mission -to offer those fiscal helps in a financially feasible way. Maintaining and balancing both at the same time is very challenging and complex task for the board of managers and senior executives who delivers strategic vision to the institutions (Vishwakarma, 2015).

This need arises from the likely clash of concern amidst participants (shareholders) in the corporate structure due to their different goals and preferences on the one hand and their flawed information as to each other's activities, understanding and preferences on the other hand (Imam \& Malik, 2007). Board of directors are constituted to protect the interest of shareholder and to ensure that the banks are manage effectively without bias. "However, there is a belief that the number of directors can affect the performance of a bank, especially its financial performance, a number of scholars have contended that larger boards have their benefits and when board size increases firm performance also goes up as more board members provide greater monitoring, advice and make available better linkages to the external environment (Pfeffer, 1972 as cited by Geoffrey, 2015)" ( $p$; 4). Nevertheless, the examination of the way in which the number and proportions of directors affect their interaction and the board ability to monitor management activities played a crucial role in board effectiveness. The audit committee is a critical link between a company's economic recording purpose and its outer shareholders (Bolton, 2010). They are the subcommittee of the board of director with the responsibility of overseeing the financial transaction of the company. "Accounting scandals and concerns about the quality of financial statements have led to many calls for improved audit committee effectiveness in many organizations (Bronson et al., 2009), one of the important diversity dimensions for organizations is the gender diversity, the dramatic increase in the percentage of female employees in various organizations has heightened the interest into the value added potential of women in the top management echelon and while gender diversity became an important issue almost for all of the organizations, diversity is important both at the employee level and at the managerial level as well, apart from the managerial positions, women are also being increasingly present in the boards, these is due to the increase in concern for corporate governance, as a result of 
MANAGEMENT SCIENCES

Vol. 11, No. 2, 2021, E-ISSN: 2225-8329 @ 2021 HRMARS

the collapse of some giant companies such as Enron, Lehman Brothers, WorldCom, after the corporate scandals, board diversity is emphasized widely both by the regulators and academics, fatherly, research into the presence of women on the board is directly connected with other aspects of corporate governance, and these include the importance of a good relationship with stakeholders, as proposed by both stakeholder theory (Donaldson \& Davis, 1991) and resource dependence theory (Pfeffer \& Salancik, 1978), diversity as a measure of independence as advocated in agency theory (Jensen \& Meckling, 1976), and diversity as a necessity for fair and transparent decision-making in an organization, therefore, the focus of this study is to ascertain how management of microfinance banks in Nigeria can enhance their performance" $(p ; 5)$.

\section{Objectives of the Study}

The overall objective of these work was to investigate the association amidst corporate governance and performance of board of microfinance banks in Nigeria. Specifically, the study seeks to:

1. Determine the correlation among directors' independence and functions of microfinance banks in Nigeria.

2. Investigate the relationship amidst gender diversity and performance of microfinance banks.

\section{Hypotheses}

Ho1: Significant relationship among board independence and performance of microfinance banks does not exist.

Ho2: There is no substantial connection among gender diversity and microfinance banks performance

\section{Theoretical Frameworks}

The notion of corporate governance can be best understood from a proper examination of theories that try to underpin the rationale behind this management imperative. Abdullah and valentine (2009) identified four fundamental theories of corporate governance: *. Stewardship theory*, *. stakeholder's theory, Resource-dependency theory, Agency theory. This study was anchored on *. stakeholders' theory* and resource dependency theory

Stakeholders' Theory

This theory was originally proposed by Richard Edward Freeman in 1984, in his book titled 'Strategic management: A stakeholder's approach". This theory opined that establishments are not purely regulated by persons that exercise proprietorship rights (shareholders) in the organization. Stakeholders' theory affirms that businesses devise a social responsibility that respect the benefits of every groups touched by their actions (Branco \& Lucia, 2007). A stakeholder is any person or groups of persons that has direct or indirect influence on the firm's operations. Freeman(1984) as one of the pioneer and promoters of stakeholder theory, recognized the appearance of stakeholder groups as essential components to an institutions. Freeman (1984) state that stake-holders as any gathering individuals or person who can influence or is influenced by the accomplishment of the organization's goals. He further recognized the rise of stakeholder bunches as significant components to the organization specifying thought. He further proposes a re-building of hypothetical viewpoints that stretch out past the owner manager-employee position and 
MANAGEMENT SCIENCES

Vol. 11, No. 2, 2021, E-ISSN: 2225-8329 @ 2021 HRMARS

perceives the various gathering such as the Government, shareholders, political parties, distributors, patrons, traders' associations, employees and communities. "Sundaram and Inkpen (2004) also suggest that stakeholder theory attempts to address the question of which groups of stakeholder deserve and require management attention, according to Smallman (2004), the main criticism of stakeholder theory is focusing on identifying the problem of who constitutes genuine stakeholders, also, Rusconi (2009) posits that the fundamental basis of the stakeholder theory is normative and involves the acceptance of ideas that stakeholders are persons or groups with legitimate interests in procedural and/or substantive aspects of corporate activity and that the interest of all stakeholders are of intrinsic value, the proponents of stakeholder theory believe that by looking after the stakeholders, acting morally and attending to stakeholders' social purposes, the company can become more successful (Letza, Sun \& Kirkbride, 2004)" (p;19).

Resource Dependency Theory

Pfeffer and Salancik (1972) established the above postulation. The theory is of the view that the organizations depend on resource from external environment which has a direct bearing on corporate governance structure in relations of the planned management of that organization. The directors bring in their knowledge, experience and skills to the organization in order to effectively manage or mitigate the uncertainty in cost transaction and external environmental influence. Hence, the managers are responsible for the day-to-day management and operations of the firm. Chin, and Paladino (2004) stress that assets dependency theory originated from OST as such organizations having changing degrees of necessity on the external ecosystem, mainly for the assets they need to function. According to Fang, Huang and Huang (2010), the resource dependency hypotheses asserts that organizations must depend on treasured resources provided by its ecosystem to guarantee nonstop processes, hence the administration will change dependence on partners who can deliver dynamic resources and affects its distribution planning.

"Lawrence and Lorsch (1967) linked the assets reliance hypothesis as an ecological impact to corporate administration and they contended that effective organizations possess internal structures that match outer demand, Pfeffer and Salancik (1972) affirmed this contention and clarified that board size and its arrangement is a sound organizational response to the states of the outer environment and he further argued that external free directors may serve to associate the outer assets with the firm to beat vulnerability, which is significant for long haul maintainability" $(p ; 20)$.

Application of the Theories to the Study

The relevance of stakeholder theory to the study is the theory argued that since microfinance banks have other relevant stakeholders besides the shareholders' that have influence on its operations. It means that those external influencers such as government, communities representative, suppliers, political group and other regulatory bodies should also be involved when strategizing and implementing corporate governance policies as that will enhance the bank performance. The relevance of resource dependency theory to the study is that the theory sees the board composition and size as a rational response to everchanging business environment. Microfinance banks in Nigeria should always ensure that the independent directors are consulted while preparing medium- and long-term strategic plan of the bank as most of the independent directors come with diverse knowledge, skills and experience which will enhance their corporate performance 
MANAGEMENT SCIENCES

Vol. 11, No. 2, 2021, E-ISSN: 2225-8329 @ 2021 HRMARS

\section{Concept of Corporate Governance}

Corporate governance is the process of bringing the interest of the shareholder, managers and other stakeholders in one accord, in order to ensure that no party especially the managers do not deviate from organizational set goals and responsible practices. "The policies, rules, processes, practices and programs used by an institution in administering, directing and controlling the operations and its affairs is generally constitute the elements and instruments of its corporate governance (Duke II \& Kankpang, 2011), corporate governance within its core structure is thus concerned with the organizational functionality as well as the distribution of power among its various stakeholders (Johnson \& Scholes, 1997), and Hill and Jones (2001) assert that corporate governance from a managerial perspective refers to the controls used to ensure that managers' actions are consistent with the interest of key constituent shareholders, evidently, the definition of corporate governance seems to vary along one's view of the world (Shahin \& Zairi, 2007), in spite of these variations, scholars seem to have built consensus and generally settled on three main components of corporate governance (Mazudmer, 2013), but the first component is outlined as the corporate governance philosophy which under pins the goal for which the corporation is governed, while the second component comprises the roles and relationships among a company's management, its board, its shareholders and other stakeholders, lastly the third component comprises the firm's domicile regulatory and market mechanisms" $(p ; 25)$.

Corporate governance could also be seen as the relationship that occurs among the principal and agent, agent and the stakeholders in maximizing shareholders wealth and ensuring effective organizational performance. From agency theory point of view as a guide, the necessity for corporate governance arose from separation of the ownership of the firm from its control. The disconnection of possession from the management is traceable to the start of the era thru the emergency of the big, public establishments with a wider shareholders base, the 'managerial' firm, where the managers do not hold a significant share of the company's capital (Charreux, 2004). However, this crisis has transformed into a different dimension, where the agent is working solely to satisfy his selfish interest at the detriment of the shareholders. On the other hand, the shareholders often lack access to information that is vital to exercise control over the agent of the firm. Therefore, corporate governance arose out of the necessity to defend the awareness of the bondholders and the investors by controlling the activities of their managers (Stanwick \& Stanwick, 2002). There is a wide range of definitions and perspective on the concept of corporate governance due to variations in each country's experience, legal systems and historical circumstance. Thus, a universally acceptable definition of the concept is difficult, because corporate governance practices are not uniform across nations. "Corporate Governance, therefore, refers to the manner in which the power of a corporation is exercised in the stewardship of the corporation's total portfolio of assets and resources with the objective of maintaining and increasing shareholder value and satisfaction of other stakeholders in the context of its corporate mission (Chenuos, Mohamed, \& Bitok, 2014), corporate governance refers to the systematic processes by which the business activities of an institution are directed and managed, in order to maximize long term shareholders wealth and enhance corporate performance, while a number of corporate governance mechanisms have been proposed to solve the principal-agent problem between principals' and their agents, these governance mechanisms as identified in agency theory include board size, board composition, CEO pay performance sensitivity, directors' ownership and shareholders right (Gomper, Ishii, \& Metrick, 2003), the overall objective of corporate governance is to solve agency conflict and 
MANAGEMENT SCIENCES

Vol. 11, No. 2, 2021, E-ISSN: 2225-8329 @ 2021 HRMARS

ensure transparency in the internal and external activities of the institution in other to enhance long-term value for all stakeholders through improved financial returns on their invested wealth, and Central Bank of Nigeria (2006) noted the importance of corporate governance by stepping up its regulatory authority and issuing a code of corporate governance to banks under its supervision, thus, it was necessary due to the rampant cases of corporate scandals around the world and among Nigeria banks, despite the importance of corporate governance to business performance, a survey by Securities and Exchange Commission of Nigeria (SEC, 2011) reveals that corporate governance was at a rudimentary stage, as only about 40 percent of quoted companies including banks recognize code of corporate governance" (p;26).

It has been observed that institution of corporate governance code, many top management staff and board members can still collude to override checks and balance put in place to safeguard organizational assets. Hill and Jones (2004) opine that strong corporate governance procedures are important to ensure that managers adhere strictly to the ethical norms and expectations of the society in which they operate. They observed further that there are five cornerstones of strong corporate governance, which are as follows:

1) The panel of directors ought to be constituted of directors who have no management responsibilities in the firm.

2) The CEO and board chairmanship position shall hold by separate persons.

3) The reimbursement team should be composed fully of outside directors.

4) There should be an audit committee to review the financial statements of the firm.

5) The board should use outside auditor who are truly independent to audit the firms accounts.

According to Kazmi (2008), managing the relationship between the directors and managers of an organization and other stakeholders is the central theme of corporate governance. He summarized the organizational mechanism to ensure good corporate governance as follows;

a) Ensuring an effective board of directors.

b) Being committed to a code of governance.

c) Ensuring a sound internal control system.

d) Instituting transparency in all fields of the organization's activities.

e) Having an effective auditing and evaluation systems within the organization.

The cardinal principles of good corporate governance were summarized by the CBN (2006) as follows:

a) Corporate structures transparency and operations

b) Accountability of board members and shareholders towards corporate responsibility of organizational internal and external environment.

\section{Concept of Independent Board}

The board of directors is an institution of persons appointed by the shareholders to which managers of a firm are accountable for, over the firms' day to day activities. It is an undisputable fact that board of director is the highest organ in any organizational structure. The board of director is elected by the shareholder with the responsibility of monitoring the activities of the top management, and ensuring adequate returns on stockholders' investment. The board of directors comprises both the internal and external independent board members appointed by the shareholders. The board independence has an important bearing to the organizational effectiveness. Independent director is a director that does not 
MANAGEMENT SCIENCES

Vol. 11, No. 2, 2021, E-ISSN: 2225-8329 @ 2021 HRMARS

have a direct affliction with the internal management activities other than a company director. Dalton, et. al., (1998), Daily, et. al., (2003), and Naveen and Singh (2012) labelled the nonexecutive and autonomous directors as very critical elements for guaranteeing business responsibility. Still, Fama and Jensen (1983); Adebayo, Olusola and Abiodun (2013) concluded that the independent executives play a substantial pact in the actual firmness of agency bottle-necks of a business and therefore their existence can lead to straightening and further operative result-making in the firm. Fama and Jensen (1983); and Bebeji, Mohammed and Tanko (2015) claim that external executives have the inducement to perform as observers of management because they want to safeguard their standings as effective and independent decision makers. The presence of the independent directors on the organizational boards provides connection for the company for diverse opportunities. "Independent directors provide neutral insights, bring in fresh, creative perspectives and help in decision-making by bringing in new dimensions of experiences (Yasser, 2011), Bebeji, Mohammed and Tanko (2015) opined that independent board of directors has fewer conflicts of interest in monitoring managers, even if the presence of outside directors entails additional costs to the firm (fees, travel expenses, etc), after the recent corporate scandals, policy makers and regulators worldwide have called for greater independent of boards of directors from the top management of firms (Dalton \& Dalton, 2005), firms with greater percentage of board independence are the most effective deterrent of fraudulent financial reporting, consequently, businesses that are committing financial reporting fraud are more likely to have a board of directors dominated by insiders (Dechow, Sloan, \& Sweeney, 1996; Beasley, 1996; Beasley, Carcello, Hermanson, \& Lapides, 2000; Song \& Windram, 2004), also, Romano and Guerrini (2012) urged that the higher the percentage of independent directors on the board, the lower the likelihood of financial fraud, arguing that a higher relative weight of independent directors appears to ensure more effective control, in contrast, De Andres and Vallelado (2008) opined that excessive proportion of non-executive directors could damage the advisory role of boards, since executive directors facilitate the transfer of information between directors and management and give information and knowledge that outside directors would find difficult to gather" $(p ; 31)$.

\section{Concept of Board Gender Diversity}

Board gender diversity is the proportion of both male and female delegated at the corporate board. One of the significant variety measurements scopes for organizations is the sexual variety. Due to the sensational increment in the level of female employees, sexual orientation diversity has turned into significant issue for all of the associations. Also, it is significant for both workers echelon and at the administrative level too. Aside from the administrative ranks, ladies are likewise being progressively present in the boards. After the ongoing embarrassments, board assorted that gender diversity should accentuated broadly both the controller and scholastics. "Over the last two decades, there have been debates about board gender diversity as a sub-set of board diversity in other to improve and foster good corporate governance (Plessis, Saenger \& Foster, 2012), board gender diversity has become a widely discussed topic within corporate governance, despite there has been a decisive trend to promote women at top management positions and some advances have been achieved, a vast majority of boardrooms are still composed of male directors (Jourová, 2016), according to Campbell and Mínguez-Vera (2008), board gender diversity is based on both ethical and economic arguments, beyond the ethical implications, the women's representation in top positions of the corporate hierarchy may have important repercussions 
MANAGEMENT SCIENCES

Vol. 11, No. 2, 2021, E-ISSN: 2225-8329 @ 2021 HRMARS

for business performance, not only as a signal of a more gender-neutral recruitment and promotion process, but also because of the potential benefits of gender diversity itself in terms of broadening the range of experience and expertise as well as human capital available to a team (Adams \& Ferreira, 2009), in addition to the ethical considerations of diversity, there exist studies demonstrating the effect of board gender diversity on performance, but on one side, many research shows that firm performance have a positive and direct relation with gender diversity in the board of directors of a firm (Carter, Simkins \& Simpsonr, 2003; Bonn, 2004; Farrell \& Harsch, 2005), while on the other side, negative correlation was found between gender diversity and firm performance (Smith, Smith \& Verner, 2006; Eklund, Palmberg \& Wiberg, 2009; Darmadi, 2011), recently, Laffarga, Pilar and Reguera-Alvarado (2015) have found a positive relationship based on a Spanish sample too, and they attribute it to the fact that women are more risk-averse than men, as they tend to propose less aggressive and more sustainable investment strategies, though the results are conflicting, it is evident that more research suggests that gender diversity increase in performance because of reasons like, culture of questioning, lack of sufficient qualified directors (Burke, 2000), it is believed that women directors consider a spectrum of stakeholders before making a decision, women are perceived as having a spectacular understanding of consumer behavior and needs (Brennan \& McCafferty, 1997), however, in decision-making, female directors are said to have risk-averse trait than their counterpart, they also shun overconfidence (Byrnes, Miller \& Schafer, 1999; Barber \& Odean, 2001), according to Croson and Buchan (1999), women are more trustworthy and collaborative than men and this can improve board dynamics, men and women have different perceptions; female directors can bring conflicting views, new knowledge, different perspectives, and more alternative solutions to problems (Dang, Nguyen $\&$ Vo, 2012), therefore, women are blessed with unique traits that can significantly shape the strategic direction of a firm and positively add to the growth and development of the corporation (Lincoln \& Adedoyin, 2012)" (p;35).

\section{Concept of Banks Performance}

Good financial performances of the bank bring back good returns to the bondholders for their asset and attract more investors which will bring further economic development. Consequently, meagre routine of financial institutions may hint to their downfall and arrival of the capital disaster which will have negative ramifications on the company and economic development (Nuhiu, Hoti \& Bektashi, 2017). "Banking industry is a very important sector because the development of finance, and particularly the banking system, promotes economic growth (Lipunga, 2014), the banking system plays a major role in transferring funds from the saving units to the investing units (Nshimiyimana \& Zubeda, 2017), they are important for the economy and organizations in particular at the time of economic recession and money related crisis, industrial, agricultural and commercial development of a country is not imaginable without an efficient banking system, sometimes banks truly do not respond to crisis, by comparing the latest financial crisis of 2007-09, it made conditions more terrible for economic improvement, it is significant to observe the performance of banks with the administrative prerequisites (Babar \& Zeb, 2011), the financial performance of the bank is affected by the function of internal and external factors, internal factors refer to the indicators derived from the financial statements of banks (balance sheet and income statement) and therefore can be regarded as specific factor of banks' profitability (Wahdan \& Leithy 2017), external factors are variables that are not related to the management of the bank, but they reflect the economic and regulatory environment that affect indirectly in the 
MANAGEMENT SCIENCES

Vol. 11, No. 2, 2021, E-ISSN: 2225-8329 @ 2021 HRMARS

operation and profitability of the banks (Tobias \& Themba, 2011). Bank performance therefore, could be seen in term of how the management operates or the result of their actions" (p;42).

\section{Empirical Review}

Akbar, (2014) conducted a study on corporate governance and businesses performance: evidence from textile sector of Pakistan. "The data set includes 11 listed textile companies from 2007 to 2011, spearman's correlation and analysis of variance was used to discover this relationship, the rationale for the study is to examine the relationship between three important corporate governance mechanisms (ownership concentration, board size, CEO duality) and two firm performance proxies (return on assets and returns on equity), however, result revealed a positive relationship between ownership concentrations and ROA and a positive relationship between CEO duality and ROA but observed no significant relationship between board size and ROE; however, ROE is positively correlated with ownership concentration and CEO/chair duality, the result indicates that the predicting variables like board size, ownership concentration, and CEO duality affected the performance of different firms differently, outcomes from the multiple regression revealed that ownership concentration has positive relationship with firm performance proxies, however, board size has a positive and significant relationship with ROA, the study concluded that corporate governance has a positive and significant effect on the firm performance in textile sector of Pakistan"(P;47). The study recommended that Pakistan Company should adopt small board size which has a positive contribution towards firm performance. Corporate governance practices should be improved in textile sector of Pakistan so as to boost company's operations and financial performance.

Gap: the present study concentrated on microfinance banks in Nigeria as corporate governance practice varies from country to country, institution to institution. This implies that the findings from the above study may not be generally applicable to the corporate governance operations in microfinance banks in Nigeria.

Okoye, Adedayo, Ahmed and Isibor (2017) explored a study on the association amidst corporate governance and financial maintainability of the micro finance establishments within Nigeria during the period, 2011 to 2015. Financial sustainability was measured through the use of ROA and operating self-sufficiency (OSS). Board independence (BRDIND), board size (BRDSIZE) and gender diversity (GENDIV) were adopted as corporate governance attributes or proxies. The study concentrated on only national and state category of microfinance banks in Nigeria. The data were examined using discrete methods and correlation followed by a regression result. Findings reveal that there is no substantial relationship among corporate governance mechanisms (board independence, gender diversity) and financial sustainability. Only board size shows a positive relationship with financial sustainability. The study therefore recommends that microfinance banks should adopt gender friendly policies thereby encouraging more women to the membership of microfinance banks' Boards to take advantage of their expected benefits. Also, the study further recommends that the regulatory authorities should ensure that Microfinance within Nigeria comply strictly with corporate governance code and sanctions should be meted to erring banks.

Gap: the study bridged the gap by including all the category of microfinance banks in Nigeria as that will give equal attention in determining the influence of board activities on their performance. Furthermore, the present work utilizes profit on assets and liquidity as 
MANAGEMENT SCIENCES

Vol. 11, No. 2, 2021, E-ISSN: 2225-8329 @ 2021 HRMARS

performance measurement variable and it is considered by scholar as the most acceptable indicators of banks profitability. Also, the study examines the nexus among corporate governance and performance of microfinance bank in Nigeria as corporate governance issues in commercial banks may not be peculiar with microfinance banks.

\section{Methodology}

longitudinal research design was used. Longitudinal design is a type of correlational research that involves studying a variable over an extended period of time. The study was conducted on all the licensed microfinance banks operating in Nigeria as at $31^{\text {st }}$ December 2020. The technique of sampling employed is simple random technique and Taro Yamane's formula used to determine the sample size at 284. Secondary data gotten from examined financial position of the chosen licensed microfinance banks in Nigeria between the five years period of 2015 and 2019. This study also made use of information from the corporate records and other linked resources especially the Central Bank of Nigeria yearbook supervision reports. Pilot study was employed to test the reliability of the instrument. A pilot study involves pretesting of a research tools such as new data collecting method. In this case, six microfinance banks were randomly selected from the sampled institutions in order to check if the independent variables were manipulated correctly and the test measure is appropriate. And the reliability test was at $86 \%$. Descriptive statistics and multiple regression were used to analyze the data with the help of SPSS version 20.

Model specification Model A

In accordance with the above objectives and hypotheses, the model is stated thus;

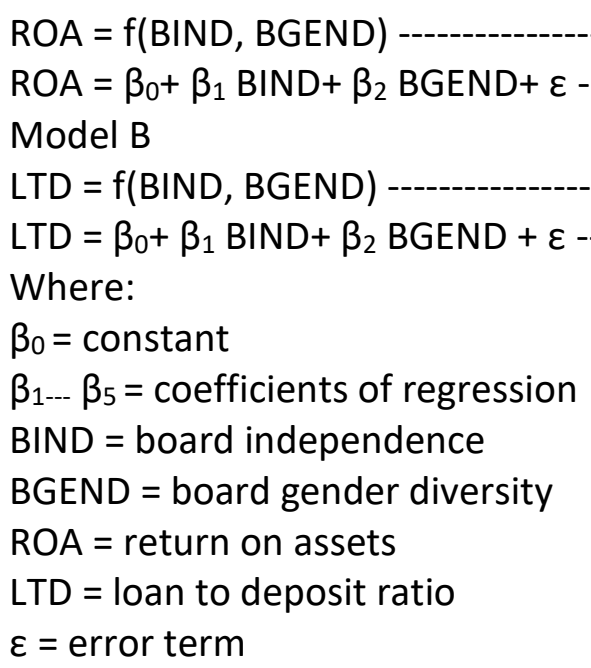

Table 1.1

Summary of descriptive statistics

\begin{tabular}{|c|c|c|c|c|c|}
\hline & $\begin{array}{l}\text { Observatio } \\
\text { ns }\end{array}$ & $\begin{array}{l}\text { Minimu } \\
\mathrm{m}\end{array}$ & $\begin{array}{l}\text { Maximu } \\
\mathrm{m}\end{array}$ & Mean & $\begin{array}{l}\text { Std. } \\
\text { Deviation }\end{array}$ \\
\hline Board Independence & 1420 & 2.00 & 4.00 & 2.8462 & .77522 \\
\hline $\begin{array}{l}\text { Board } \quad \text { Gender } \\
\text { Diversity }\end{array}$ & 1420 & .00 & 4.00 & 1.2308 & 1.05726 \\
\hline Return on Assets & 1420 & .10 & .37 & .1815 & .06636 \\
\hline Liquidity & 1420 & .83 & 3.46 & 2.0300 & .45063 \\
\hline Valid N (listwise) & 1420 & & & & \\
\hline
\end{tabular}

*.Source: SPSS Output(2020) 


\section{MANAGEMENT SCIENCES}

Vol. 11, No. 2, 2021, E-ISSN: 2225-8329 @ 2021 HRMARS

The above table presents the descriptive statistics of the explanatory and dependent variables. It shows that there are 1420 observations (5 years annual financial reports computation of 284 sampled microfinance banks) in Nigeria. The average board independent directors' ratio is 2.85 percent of board members. This low value shows the need for more directors without direct or indirect financial interest on corporate boards. With the minimum number of 2 and maximum number of 4 independent board directors. while the average proportion of female directors' is 1.23 percent which signals a low participation of females on the board of microfinance banks in Nigeria. The highest number of board members that were women is 4 while some boards did not have women presence. With the minimum number of 0 , some board failed to include women directors while others had as many as 4 .

TABLE 1.2

Model Summary

\begin{tabular}{|l|l|l|l|l|}
\hline Model & & R Square & $\begin{array}{l}\text { Adjusted } \\
\text { Square }\end{array}$ & $\begin{array}{l}\text { S.td. Error of the } \\
\text { Estimate }\end{array}$ \\
\hline 1 & $.172^{\mathrm{a}}$ & .030 & .035 & .06752 \\
& & & & \\
& & & & \\
\hline
\end{tabular}

*.a. Predictors: (Constant), Board Gender Diversity, Board Independence.

TABLE 1.3

ANOVA $^{b^{*}}$

\begin{tabular}{|c|c|c|c|c|c|c|}
\hline & & & ANOV & & & \\
\hline Model & & Sum & $f$ & & & \\
\hline & & Squares & Df & Mean Square & $\mathrm{F}$ & Sig. \\
\hline 1 & Regression & .008 & 2 & .002 & 1.458 & $.000^{\mathrm{a}}$ \\
\hline & Residual & .274 & 1417 & .005 & & \\
\hline & Total & .282 & 1419 & & & \\
\hline
\end{tabular}

*.a. Predictors: (Constant), Board Gender Diversity, Board* Independence

b. Dependent Variable: Return on Assets 
TABLE 1.4

Model

\section{Coefficients $^{\mathrm{a}}$}

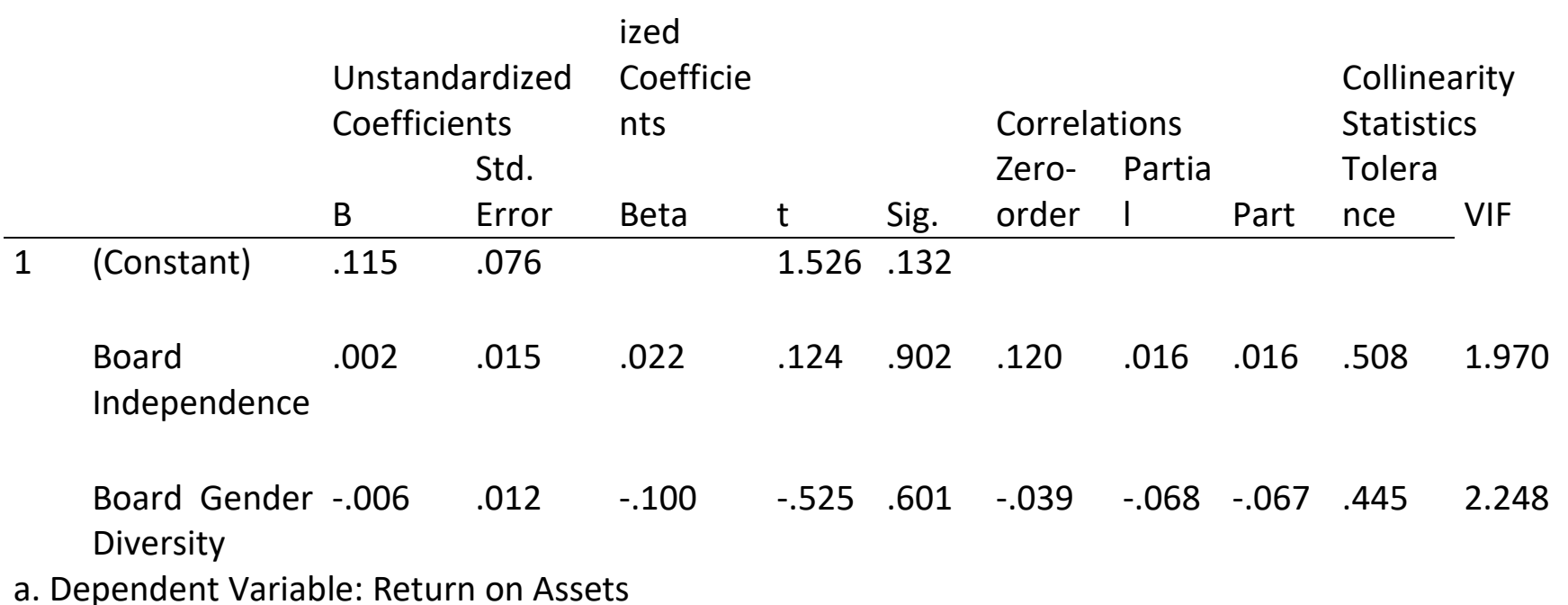

Source: SPSS Output, (2020)

TABLE 1.5

Model Summary

\begin{tabular}{|c|c|c|c|c|c|}
\hline Model & $\mathrm{R}$ & R Square & \begin{tabular}{|ll} 
Adjusted & $R$ \\
Square & \\
\end{tabular} & $\begin{array}{l}\text { Std. Error of } \\
\text { the Estimate }\end{array}$ & $\begin{array}{l}\text { Durbin- } \\
\text { Watson }\end{array}$ \\
\hline 1 & $.347^{a}$ & .120 & .062 & .43653 & 2.410 \\
\hline
\end{tabular}

*.a. Predictors: (Constant), Board Gender Diversity, Board Independence

b. Dependent Variable: Liquidity

TABLE1.6

ANOVA $^{b}$

\begin{tabular}{lllllll}
\hline Model & & Sum & of & & & \\
& & Squares & df & Mean Square & Sig. \\
\hline 1 & Regression & 1.563 & 4 & .391 & 2.051 & $.099^{a}$ \\
& Residual & 11.433 & 1417 & .191 & & \\
& Total & 12.996 & 1419 & & &
\end{tabular}

a. Predictors: (Constant), Board Gender Diversity, Board Independence

b. Dependent Variable: Liquidity 
TABLE 4.7

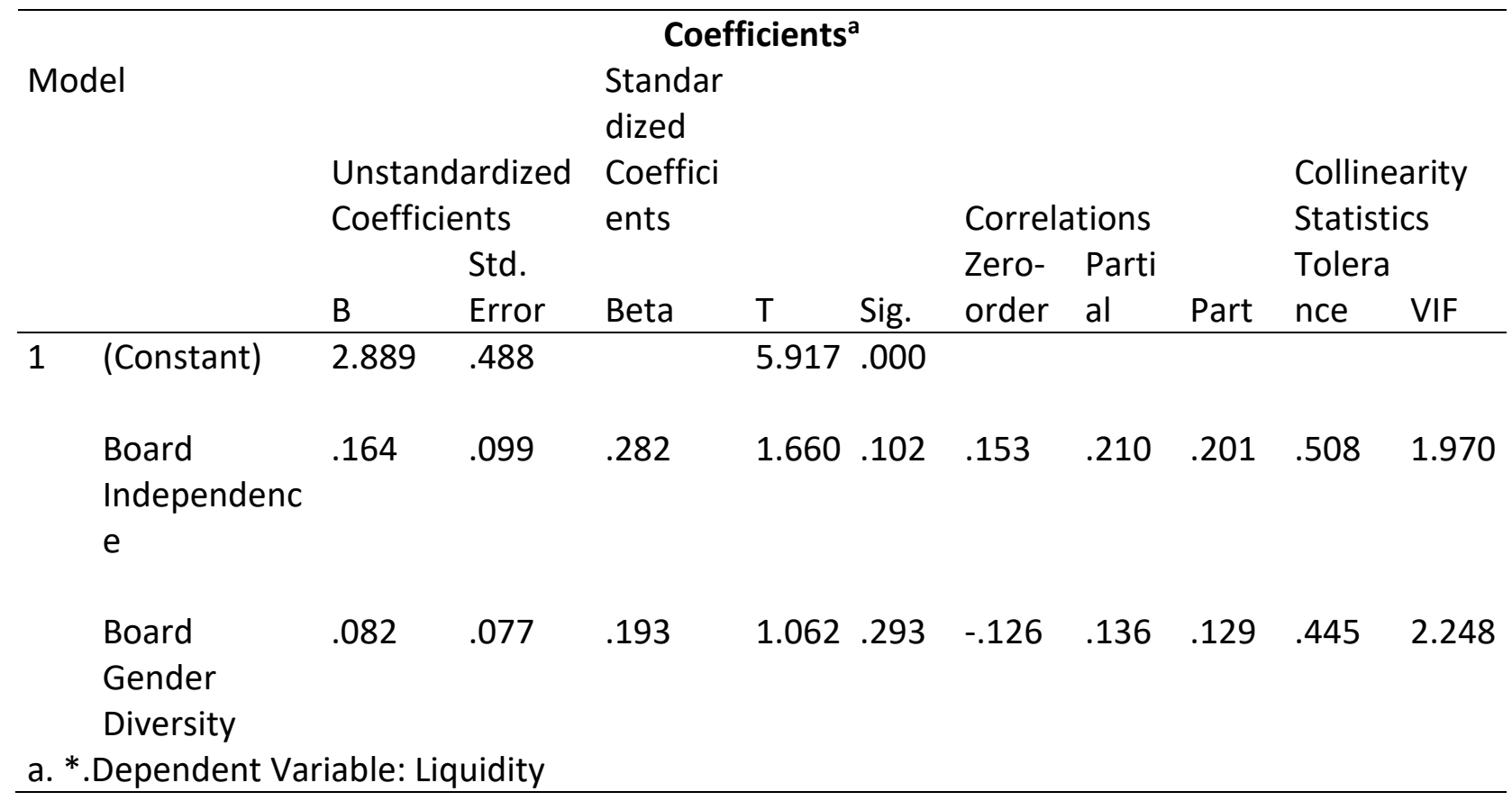

\section{Conclusion}

Corporate governance refers to the systematic procedures by which the commercial activities of an establishment are aimed and managed, in demand to maximize short/long term stockholders' wealth and enhance corporate performance. Microfinance banks in Nigeria are grossly faced with issues of how to manage limited resources (human capital) to achieve its predetermined objectives at a minimum cost. There is assumption that members of the organization will work collectively to add value to the organization. However, evidence abound that some members of the organization may work at cross-purposes to organizational goals due to conflict of interest, and it is the duty of the board to ensure that there is synergy of effort. An understanding of corporate governance mechanisms is a necessary step toward achieving organizational objectives at a minimum cost. The study considered corporate governance mechanism and concentrated on board independence and board gender diversity. The research result has shown that the above identified variables have the ability to enhance banks performance when manage properly. Performance in this study has to do with profitability and liquidity. The result from the tested hypotheses reveals that there is a substantial and positive correlation among board independence and return on assets of microfinance banks. The board gender diversity has significant and negative influence on profit on assets of microfinance banks. Furthermore, the result on liquidity reveals that there is positive and significant relationship amidst board independence, board gender diversity and liquidity of microfinance banks. However, it is observed from the study that women representation on boards of microfinance banks is still very low.

Therefore, it is imperative that regulatory bodies of microfinance banks in Nigeria to come up with a policy that will compel existing microfinance banks in Nigeria to be gender sensitive in the appointment of directors as that will help to minimize the dominants of men on the board of microfinance banks. More so, the appointed directors should be those who are knowledgeable about 
INTERNATIONAL JOURNAL OF ACADEMIC RESEARCH IN ACCOUNTING, FINANCE AND

MANAGEMENT SCIENCES

Vol. 11, No. 1, 2021, E-ISSN: 2225-8329 @ 2021 HRMARS

microfinance banks activities as that will help the management in achieving the purpose to which it was established and also place the banks in a favorable competitive edge.

\section{Contribution}

The study which centered on assessing the effect of corporate governance board characteristics on performance of microfinance banks was conducted to ascertain the impact of diversified knowledge, experiences and skills of the directors on the performance of various microfinance banks in Nigeria. The study contributed on the existing literature by focusing on valueadd potential of board gender sensitivity and independence of the board of microfinance banks as most of the study focus on commercial banks and manufacturing industry. Furthermore, the study used resource dependency and stakeholders' theory as the underpinning theory as most of the study uses Agency theory. Reasons been that microfinance banks in Nigeria are divided into three categories (unit, state and national) and the capital reserve are not the same. It is expected that the resource dependency theory will play a relevant role as it sees the board composition and size as a rational response to ever-changing business environment.

\section{Recommendations}

From the findings and conclusion of the study, the following recommendations are made:

a) There should be a greater number of independent directors' in order to ensure transparency and adequate representation of the interest of the shareholders without bias.

b) Microfinance banks should turn their attention to the value-adding potential of gender diversity by been gender sensitive while employing staff and appointing directors'. This is because a gender diversified board can expose the banks to a broader knowledge base, creativity and innovation in decision making processes thereby enhancing the banks performance.

\section{References}

Abdullahi, H., \& Valentine, B. (2009). Fundamental and ethics theories of corporate governance. Middle Eastern Finance and Economics, 1(6), 88-96.

Acha, I. A. (2012). Microfinance banking in Nigeria: Problems and prospects. International Journal of Finance and Accounting, 1(5), 106-111.

Adams, R., \& Ferreira, D. (2009). Women in the boardroom and their impact on governance and performance. Journal of Financial Economics, 94(2), 291-309.

Adebayo, O. S., Olusola, A. G., \& Abiodun, O. F. (2013). The relationship between corporate governance and organizational performance: Nigerian listed organizations experience. International Journal of Business and Management Invention, 2(9), 1-6.

Akbar, A. (2014). Corporate governance and firm performance: Evidence from textile sector of Pakistan. Journal of Asian Business Strategy, 4(12), 200-207.

Babar, H. Z., \& Zeb, G. (2011). CAMELS rating system for banking industry in Pakistan: Does CAMELS system provide similar rating as PACRA system in assessing the performance of banks in Pakistan? Master's thesis, Pakistan: Umea School of Business, Umea University.

Barber, B. M., \& Odean, T. (2001). Boys Will Be Boys: Gender, Overconfidence, and Common Stock Investment. Quarterly Journal of Economics, 116(8), 261-292. 
INTERNATIONAL JOURNAL OF ACADEMIC RESEARCH IN ACCOUNTING, FINANCE AND

MANAGEMENT SCIENCES

Vol. 11, No. 1, 2021, E-ISSN: 2225-8329 @ 2021 HRMARS

Beasley, M. S. (1996). An empirical analysis of the relation between the boards of director composition and financial statement fraud. Accounting Review, 71(4), 443-465.

Beasley, M., Carcello, J., Hermanson, D., \& Lapides, P. (2000). Fraudulent financial reporting: Consideration of industry traits and corporate governance mechanisms. Accounting Horizons, 14(4), 441-454.

Bebeji, A., Mohammed, A., \& Tanko, M. (2015). The effect of board size and composition on the financial performance of banks in Nigeria. African Journal of Business Management, 9(16), 590598.

Bolton, B. (2010). Corporate governance and firm performance. Journal of Corporate Finance, 14(3), 257-273.

Bonn, I. (2004). Board structure and firm performance: Evidence from Australia. Journal of the Australian and New Zealand, 10(1), 14-24.

Branco, M. C., \& Lucia, R. L. (2007). Positioning stakeholder theory within the debate on corporate social responsibility. Electronic Journal of Business Ethics and Organisation Studies, 12(1), 5-15.

Brennan, N., \& McCafferty, J. (1997). Corporate governance practices in Irish companies. Irish Business and Administrative Research, 18(3) 116-135.

Bronson, S. N., Carcellor, J. V., Hollingworth, C. W., \& Neal, T. L. (2009). Are fully independent audit committee really necessary?. Journal of Accounting and Public Policy, 28(4), 265-280.

Burke, R. J. (2000). Company size, board size and the number of women directors. In R. J. Burke and M. C. Mattis (eds). Women on corporate boards of directors: International challenges and opportunities, 157-167.

Byrnes, J. P., Miller, D. C., \& Schafer, W. D. (1999). Gender differences in risk taking: A meta-analysis. Psychological Bulletin, 125(5) 367-383.

Campbell, K., \& Minguez-Vera, A. (2008). Gender diversity in the boardroom and firm financial performance. Journal of Business Ethics, 83(3), 435-451.

Carter, D. A., Simkins, B. J., \& Simpson, W.G. (2003). Corporate governance, board diversity, and firm value. The Financial Review, 38(6), 33-53.

Central Bank of Nigeria. (2006). Code of corporate governance for banks in Nigeria post consolidation. Zenith Economic Quarterly, 1(6), 11-14.

Charreaux, G. (2004). Corporate governance theories: from micro theories to national systems theories. Working Paper of FARGO.

Chenuos, N. K., Mohamed, A., \& Bitok, S. K. (2014). Effects of corporate governance on microfinance institutions. European Journal of Business and Management, ISSN 2222-2905

Chin, J., Widing II, R., \& Paladino, A. (2004). Influence of resource dependency theory on firm performance, managing the competitive environment. Retrieved from AnANZMAC Web site: smib.vuw.ac.nz:8081/WWW/ANZMAC2004/ CDsite/papers/Chin1.PDF

Croson, R., \& Buchan, N. (1999). Gender and culture: International experimental evidence from trust games. American Economic Review, 89(4) 386-391.

Daily, C. M., Dalton, D. R. \& Canella, A. A. (2003). Corporate governance: Decades of dialogue and data. Academic Management Review, 28(3), 371-382.

Dalton, C. M., \& Dalton, D. R. (2005). Boards of directors: Utilizing empirical evidence in developing practical prescriptions. British Journal of Management, 16(1), 91-97. 
INTERNATIONAL JOURNAL OF ACADEMIC RESEARCH IN ACCOUNTING, FINANCE AND

MANAGEMENT SCIENCES

Vol. 11, No. 1, 2021, E-ISSN: 2225-8329 @ 2021 HRMARS

Dalton, D. R., Daily, C. M., Ellstrand, A. E. \& Johnson, J. L. (1998). Meta-analytic reviews of board composition, leadership structure and financial performance. Strategic Management Journal, 19(5), 269-290.

Dang, R., Nguyen, D. K., \& Vo, L.C. (2012) .Women on corporate boards and firm performance: A comparative study. Paper presented at AFFI Conference.

Dar, L. A., Naseem, M. A., Rehman, R. U. \& Niazi, G. S. K. (2011). Corporate governance and firm performance: A case study of Pakistan oil and gas companies listed in Karachi stock exchange. Global Journal of Management and Business Research, 11(8), 1-9.

Darmadi, S. (2011). Board diversity and firm performance: The Indonesian evidence. Corporate Ownership and Control, 9(1), 524-539.

De-Andres P., \& Vallelado, E. (2008). Corporate governance in banking: The role of the board directors. Journal of Banking and Finance, 32(12), 2570-2580.

Dechow, P. M., Sloan, R. G., \& Sweeney A. P. (1996). Causes and consequences of earnings manipulation: An analysis of firms subject to enforcement actions by the SEC. Contemporary Accounting Reset, 13(1), 1-36.

Donaldson, L., \& Davis, J. H. (1991). Stewardship theory or agency theory, CEO governance and shareholder returns. Australian Journal of Management, 6(1), 49-65.

Duke II, J., \& Kankpang, K. (2011). Linking corporate governance with organizational performance: New insights and evidence from Nigeria. Global Journal of Management and Business Research, 11(2), 47-57.

Eklund, J. E., Palmberg, J., \& Wiberg, D. (2009). Ownership Structure, Board Composition and Investment performance. CESIS Electronic Working Paper Series, Paper no. 172

Fama, E. F., \& Jensen, M. C. (1983). Separation of ownership and control. Journal of Law and Economics, 26(2), 284-301.

Fang, S., Huang, C., \& Huang, S. W. (2010). Corporate social responsibility strategies, dynamic capability and organizational performance. Case of top Taiwan selected bench mark enterprises. African Journal of Business Management, 4(1), 120-132.

Farrell, K. A., \& Hersch, P. L. (2005). Additions to corporate boards: The effect of gender. Journal of Corporate Finance, 11(2) 85-206.

Freeman, E. (1984). Strategic management: A stakeholder approach. Englewood Cliffs, NJ: PrenticeHall.

Geoffrey, O. M. (2015). The effect of corporate governance on the financial performance of microfinance institutions in Kenya. An unpublished thesis submitted to the graduate school, University of Nairobi

Gompers, P. A., Ishii, J. L., \& Metrick, A. (2003). Corporate governance and equity prices. Quarterly Journal of Economics, 118(1), 107-155.

Hill, C. W. L., \& Jones, G. R. (2004). Strategic management theory, (6 $6^{\text {th }}$ edition). Boston: Houghton Mifflin.

Hill, C., \& Jones, G. (2001). Strategic management: An integrated approach (5 $5^{\text {th }}$ edition). Boston: Houghton Mifflin.

Imam, M. O., \& Malik, M. (2007). Firm performance and corporate governance through ownership structure: Evidence from Bangladesh stock market. International Review of Business Research Papers, 8(12), 88-110. 
INTERNATIONAL JOURNAL OF ACADEMIC RESEARCH IN ACCOUNTING, FINANCE AND

MANAGEMENT SCIENCES

Vol. 11, No. 1, 2021, E-ISSN: 2225-8329 @ 2021 HRMARS

Johnson, G., \& Scholes, K. (1997). Exploring corporate strategy. Journal of Banking and Finance, 22(6), 371-403.

Jourová, V. (2016). Gender balance on corporate boards, Europe is cracking the glass ceiling. The European Commission. Retrieved from http://ec.europa.eu/justice/genderequality/files/gender_balance_decision_making/1607_factsheet_final_wob_data_en.pdf Accessed 3 November 2017

Kazmi, A. (2008). Strategic management and business policy ( $2^{\text {nd }}$ edition). New Delhi: Tata McGraw Hill Publishing Company.

Laffarga, J., Pilar, D. F., \& Reguera-Alvarado, N. (2015). Does board gender diversity influence financial performance? Evidence from Spain. Journal of Business Ethics, 141(2), 11-24.

Lawrence, P., \& Lorsh, J. (1967). Organization and environment: Managing differentiation and integration. Boston: Harvard University Press.

Letza, S., Sun, X., \& Kirkbride, J. (2004). Shareholding versus stakeholding: A critical review of corporate governance. Corporate Governance: An International Review, 12(3), 242-262.

Lincoln, A., \& Adedoyin, O. (2012). Corporate governance and gender diversity in Nigerian boardrooms. World Academy of Science, Engineering and Technology, 71(8), 1853-1859.

Lipunga, A. M. (2014). Determinants of profitability of listed commercial banks in developing countries: evidence from Malawi. Research Journal of Finance and Accounting, 5(6), 41-49.

Mazudmer, M. M. M. (2013). Corporate governance practices in Japan: Postcrisis reforms, successive changes and future trends. International Journal of Business, Management and Social Sciences, $4(1), 1-11$.

Naveen, K., \& Singh, J. P. (2012). Outside directors, corporate governance and firm performance. Empirical evidence from India. Asian Journal of Finance and Accounting, 1(4), 89-103.

Nshimiyimana, Y. C., \& Zubeda, M. A. (2017). The influence of economic factors on profitability of commercial banks. International Journal of Management and Applied Science, 3(1), 14-18.

Nuhiu, A., Hoti, A., \& Bektashi, M. (2017). Determinants of commercial banks profitability through analysis of financial performance indicators: Evidence from Kosovo. Business: Theory and Practice, 18, 160-170.

Nwaogazi, A. (2010). Are some MFBs micro-finance or misfeasance institutions? Lagos: Daily Trust Newspaper.

Ogbechie, C. (2006). Corporate governance: A challenge for Nigerian banks. Retrieved from http://www.Businessdayonline.com

Okoye, L. U., Adedayo, E. O., Ahmed, A., \& Isibor, A. (2017). Corporate governance and financial sustainability of microfinance institutions in Nigeria. IBIMA Conference on Sustainable Economic Growth, Education Excellence, and Innovation Management through vision 2020, pp 4035-4045

Pfeffer, J., \& Salancik, G. R. (1978). The external control of organizations: A resource dependence perspective. New York: Harper Row

Plessis, J. J., Saenger, I., \& Foster, R. (2012). Board diversity or gender diversity? Deakin Law Review, 17(2), 207-249.

Romano, G., \& Guerrini, A. (2012). Corporate governance and accounting enforcement actions in Italy. Management Auditing Journal, 27(7), 622-638.

Rusconi, G. (2009). Stakeholder theory and business economics. Economia Aziendale, 2(8), 10-16. 
INTERNATIONAL JOURNAL OF ACADEMIC RESEARCH IN ACCOUNTING, FINANCE AND

MANAGEMENT SCIENCES

Vol. 11, No. 1, 2021, E-ISSN: 2225-8329 @ 2021 HRMARS

Securities and Exchange Commission. (2003). Code of corporate governance in Nigeria. Lagos: SEC Press

Securities and Exchange Commission. (2011). Code of corporate governance. Lagos: SEC Press.

Shahin, A., \& Zairi, M. (2007). Corporate governance as a critical element for driving excellence in corporate social responsibility. International Journal of Quality \& Reliability Management, 24(5), 753-770.

Smallman, C. (2004). Exploring theoretical paradigm in corporate governance. International Journal of Business Governance and Ethics, 1(1), 78-94.

Smith, N., Smith, V., \& Verner, M. (2006). Do women in top management affect firm performance? A panel study of 2,500 Danish firms. International Journal of Productivity and Performance Management, 55(5), 569-593.

Song, J., \& Windram, B. (2004). Benchmarking audit committee effectiveness in financial reporting. International Journal of Audit, 8(1), 195-205.

Stanwick, P. A., \& Stanwick, S. D. (2002). The relationship between corporate governance and financial performance: An empirical study. Journal of Corporate Citizenship, 14(8), 35-48.

Sundaram, A. K., \& Inkpen, A. C. (2004). The corporate objective revisited. Organization Science, 15(3), 350-363.

Tobias, O., \& Themba, M. S. (2011). Effects of banking sectoral factors on the profitability of commercial banks in Kenya. Economics and Finance Review, 1(5), 1-30.

Vishwakarma, R. (2015). Effect of governance on the performance of selected Indian microfinance institutions: An empirical study. European Journal of Business and Management, 7(4), 25-38.

Wahdan, M., \& Leithy, W. (2017). Factors affecting the profitability of commercial banks in Egypt over the last 5 year (2011-2015). International Business Management, 11(2), 342-349.

Yasser, Q. R. (2011). Corporate governance and performance: An analysis of Pakistani listed firms. Global Journal of Management and Business Research, 11(1), 2249-4588. 